\title{
TRADE-OFF ANALYSIS OF ECONOMIC GROWTH AND AIR POLLUTION EFFECTING DECREASE OF POOR ENVIRONMENTAL QUALITY IN SUMATERA UTARA PROVINCE
}

\author{
Benni Sinaga ${ }^{1 *}$, Zahari Zein ${ }^{2}$ \\ 1*) Postgraduate Program Universitas Negeri Medan \\ ${ }^{2}$ Universitas Harapan Medan \\ Email: bennisinaga@gmail.com
}

\begin{abstract}
The development of economic activities will certainly have a positive impact on increasing economic growth and also have a negative impact on pollution each year, will certainly affect the quality of the environment in the province of North Sumatera. This study aims to analyze the relationship and influence of the GDP, water pollution, air pollution and soil contamination on environmental quality in North Sumatera province both simultaneously and partially. The data used are secondary data from BPS Sumatera and North Sumatera Environmental Agency in the form of time series data from 2004 to 2014. Correlation analysis using correlation with SPSS version 20. Results of correlation coefficient analysis in this study explains that economic growth (0.945), water pollution (0.969), air pollution (0.903) have the relationship is very strong, while soil contamination (0.803) have a strong closeness with the quality of the environment in the province of North Sumatera. The results also showed that the variables of economic growth, pollution of water, air and soil are able to explain a model of environmental quality in North Sumatera province at 96.8 percent.
\end{abstract}

Key words: Economic Growth, Pollution and Environmental Quality

\section{INTRODUCTION}

conomic Development is a crucial indicator to realize and evaluate development result that is tempted by a country, more specifically in term of Economic sectors. Open annual growth rate shows how significantly well the government took part of their job in economic aspect in increasing inflation or individual profit in a certain period of time. The sustainable data of economic growth shows quality improvement in economy and opposed to that, unsustainable shows the decline improvement in Economy.

The large area of Sumatera Utara Province with multidimensional cultures and high inherited population, surely can assign external negative effects which eventually might lead to the poor environmental quality in Sumatera Utara Province. The high intense in population with amounts of natural resources make Sumatera Utara continuingly grows to fulfill the need of its community. The Economic growth in Sumatera Utara always assigned with magnitude increase of PDRB every year. Economic growth and its sustainable processes are the main conditions for the sustainability of 
regional economic development. Because the population continues to increase which means economic needs are also increasing, so that additional income is mandatory every year.

The GRDP Graphic of North Sumatera Province Period 2004-2014 sub-district is as follows:

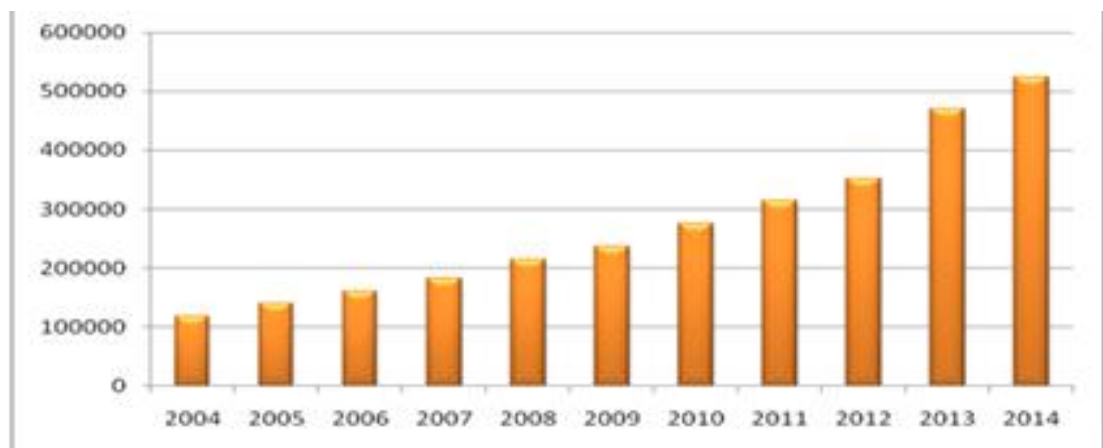

Figure 1: Development of GRDP in North Sumatera Province Period 2004-2014

Based on the Figure above, it is shown that the GRDP in North Sumatera has always increased every year and known as the highest GRDP in 2014 and ranked lowest in 2004. However, it is important to know that the increase of PDRB will certainly cause consequences for the environment in North Sumatera, including, negative external pollution, water pollution and soil environment that will have a negative impact on the environment. Undoubtedly, pollution is a social affair which required serious concern in action and controlled further because it will damage the public happiness and natural resources during process of increasing economic growth.

The index of life quality, economic growth, water pollution, air pollution and soil pollution in North Sumatera period of 2004-2014 are as follows:

Table 1: Quality Index of Environment, Economic growth, Air Pollution, Water and Soil Pollution

\begin{tabular}{|c|c|c|c|c|c|}
\hline Year & $\begin{array}{c}\text { IKLH } \\
\text { (Quotient } \\
100 \% \text { of IKLH } \\
\text { value) }\end{array}$ & $\begin{array}{l}\text { PDRB } \\
\text { Economic } \\
\text { grwoth } \\
\text { (Billion) }\end{array}$ & $\begin{array}{c}\text { water pollution } \\
\text { Domestic Liquid } \\
\text { (tCO2eq) }\end{array}$ & $\begin{array}{l}\text { Air Pollution } \\
\text { Emisector } \\
\text { Transportation } \\
\text { (tCO2eq) }\end{array}$ & $\begin{array}{c}\text { Soil Pollution } \\
\text { Land-based } \\
\text { sector (\%) }\end{array}$ \\
\hline 2004 & 1,90 & 118.100 & 721,342 & 4889,4 & 20,7 \\
\hline 2005 & 1,87 & 139.618 & 736,235 & 4898,7 & 20,5 \\
\hline 2006 & 1,73 & 160.376 & 747,564 & 4943,4 & 19,8 \\
\hline 2007 & 1,71 & 181.819 & 763,342 & 4976,9 & 19,2 \\
\hline 2008 & 1,65 & 213.931 & 789,342 & 5012,5 & 19,4 \\
\hline 2009 & 1,60 & 236.353 & 813,576 & 5078,4 & 19,8 \\
\hline 2010 & 1,58 & 275.056 & 827,275 & 5299,2 & 21,5 \\
\hline 2011 & 1,38 & 314.372 & 838,180 & 5674,4 & 21,7 \\
\hline 2012 & 1,33 & 351.090 & 849,228 & 6080,5 & 23,3 \\
\hline 2013 & 1,28 & 470.221 & 860,423 & 6520,5 & 25,8 \\
\hline 2014 & 1,27 & 523.771 & 871,765 & 6997,6 & 26,00 \\
\hline
\end{tabular}

Source: BPS Sumatera and Environment Agency North Sumatera (2015) 
Based on the table above, it shows that the economic growth assessed from the GRDP experienced an increase which proves that the economic growth experienced an increase over the years, starting from 2004 amounting to 118,100 billion to 523,771 billion in 2014. Furthermore, the quality index of the environment of life decreases, it means that the quality of the environment in Sumatera has decreased in 2004 by 1.90 to 1.27 This means that the quality of the environment in the province of North Sumatera has decreased and the need to know that in this research is high IKLH then the quality of the environment is decreasing. Then in river water pollution experienced an increase of 150,423 tCO2eq from 2004 to 871,765 tCO2eq in 2014. This means that water pollution in the province of North Sumatera experienced an increase of 150,423 tCO2eq from 2004 to 2014. Starting from 2004 amounted to 4889.4 tCO2eq to 6997.6 tCO2eq in 2014. This means that air pollution in the province of North Sumatera has increased by 2,108.2 tCO2eq from 2004 to 2014. Then the last one is land pollutant which tends to experience an increase in standards every year. From $20.7 \%$ in 2004 to $26 \%$ in 2014. This means that land pollutants in the province of North Sumatera experienced an increase of 5.3 per year from 2004 to 2014. Of course, that conditions are really worrying, the increase in economic growth has not been accompanied by real measures to reduce environmental pollution significantly and tends to increase and increase pollution and the quality of the environment over the years. This will undoubtedly have an impact on the quality of life of the community, which is decreasing every year. And it is not possible to have an impact on the decline in the productivity of the people of the province of North Sumatera with an less healthy environment, following the level of public health tend to decrease which impacted level of productivity.

Outdoor pollution comes from emissions of motor vehicles, industry, shipping, and natural processes of living things. Sources of air pollutants can be classified into stationary sources and mobile sources. Stationary sources consist of power plants, industries and households. Meanwhile, the mobile source is motorized vehicle traffic activity and sea transport. From BPS data in 2013, in several provinces, especially in big cities such as Medan, the capital of North Sumatera, motor vehicle emissions are the biggest contribution. The continuous decline in air quality over the last few years shows us how important it is to promote these emission reduction efforts. Either through outreach to the public or by conducting research for the application of emission reduction technology. Air pollution has long been a public health problem, especially in industrialized countries that have many factories and motor vehicles.

The mentioned problems earlier are seen as economically detrimental to humans, the viewed from income perspective, that if the environmental pollution is not carried out by humans, it will increase our income. Environmental pollution is a trait leading to the damage that has been done both consciously and unconsciously. In addition to detrimental income, environmental pollution also constrain stress of labor and disturbance of human health, it is difficult to find clean water. It costs a lot for some individuals. 


\section{RESEARCH METHOD}

The Object of this research was taken in North Sumatera Province. The scope of this research examines the relationship between economic growth and pollution which decrease in the quality of the living environment in North Sumatera Province, the research data combined from growth factors (GRDP) and pollution factors (water, air, and soil) and of research is conducted in North Sumatera Province. The type of data used in this research is secondary data collected from 2004 to 2014 periods. The secondary data sources obtained using documentation / literature techniques are as follows:

1. The GRDP variable is obtained from the Central Statistics Agency (BPS) of North Sumatera Province

2. Variables of Water Pollution, Air Pollution, Soil Pollution, and Environmental Quality Index (IKLH) are obtained from the official website of the Indonesian Ministry of Environment (www.kemenlh.go.id)

The research procedure used is quantitative and descriptive approach. This research was conducted d using correlation analysis with explanatory quantitative design. Correlation analysis in this study was to determine the closeness of the relationship between several independent variables, named GRDP, water pollution (river water pollution), air pollution (motor vehicle pollution), and soil pollution (land-based pollution) with the dependent variable. (Dependent variable) is the environmental quality in North Sumatera Province.

The correlation of coefficient ( $r$ ) between the variables research is obtained using the formula:

$$
r=\frac{\sum_{n=1}^{n}\left(X_{i}-\bar{X}\right)\left(Y_{i}-\bar{Y}\right)}{\sqrt{\sum_{n=1}^{n}\left(X_{i}-\bar{X}\right)^{2} \sum_{n=1}^{n}\left(Y_{i}-\bar{Y}\right)^{2}}}
$$

This coefficient value ( $r$ ) has a value between -1 and 1 . A positive value means that it has a negative correlation, while negative means that it has a correlation in the opposite direction. The results obtained later on the scale of the relationship can be compared with the scale of the strength of the relationship are as follows.

Table 2: Interpretation Guidelines for the Correlation Coefficient

\begin{tabular}{|l|l|}
\hline \multicolumn{1}{|c|}{ Coefficient Interval } & \multicolumn{1}{c|}{ Functional Relationship } \\
\hline$<0,20$ & Very low \\
\hline $0,20-0,40$ & low \\
\hline $0,40-0,70$ & Mid \\
\hline $0,70-0,90$ & strong \\
\hline $0,90-1,00$ & Very strong \\
\hline
\end{tabular}

Source: Sugiyono, 2007: 216 
RESULT AND DISCUSSION

Development of Environmental Quality Index in North Sumatera Province

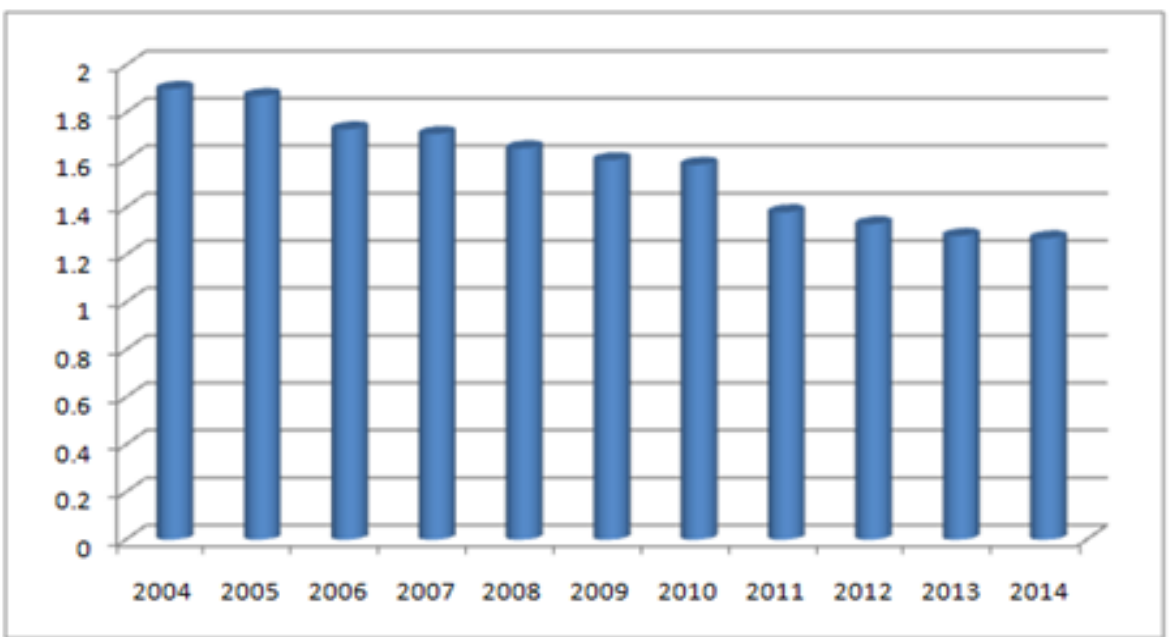

Figure 2: Environmental Quality Index of Life. North Sumatera Province 2004-2014

Based on Figure, we know that the quality of the environment in life decreased every year; which means the quality of the environment in North Sumatera has decreased during those years. It is known that in 2004 it was 1.90 to 1.27 in 2014 . This means that the index of the quality of life in the province of North Sumatera in 2014 experienced a decrease of 0.63 per year in 2004. Furthermore, in the table above, it is known that the start of the decrease in the quality of life in the Province. North Sumatera most drastically occurred in 2011 with a decrease of 0.2 percent from 1.38 percent to 1.33 percent.

\section{Development of Economic Growth in North Sumatera Province}

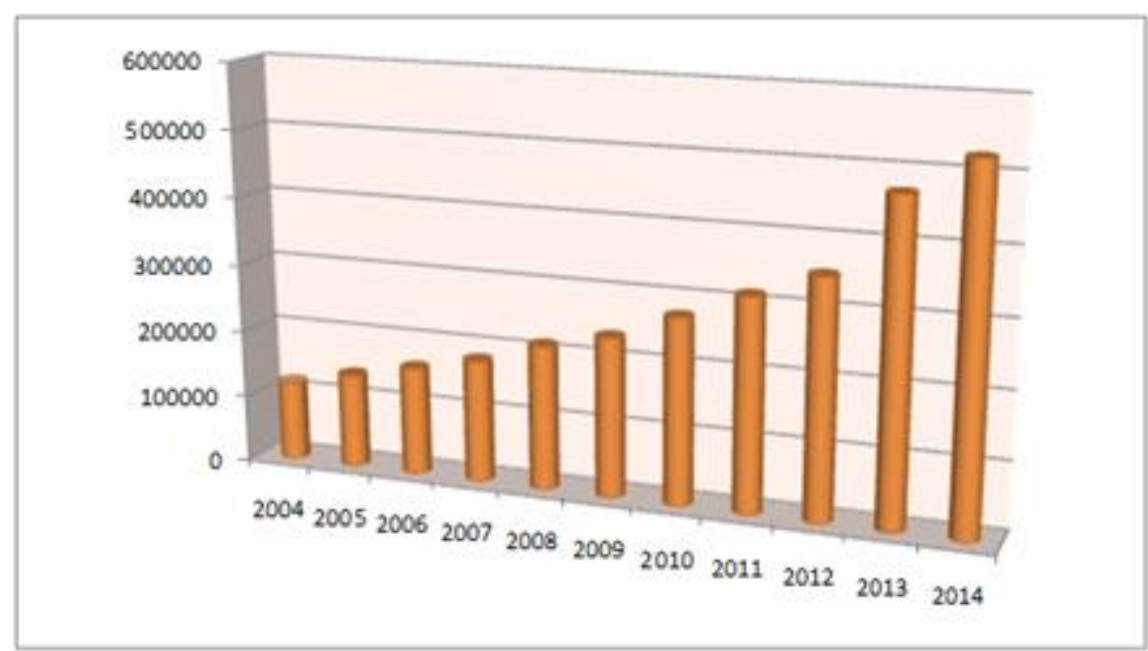

Figure 3: Economic Growth (GRDP) of North Sumatera Province 2004-2014

Based on Figure, we know that the quality of the environment in life decreased every year; it means that the quality of the environment in North Sumatera has decreased in its years. It is known that in 2004 it was 1.90 to 1.27 in 2014. This means that the index 
of the quality of life in the province of North Sumatera in 2014 experienced a decrease of 0.63 per year in 2004. Furthermore, in the table above, it is known that the start of the decrease in the quality of life in the Province. North Sumatera most drastically occurred in 2011 with a decrease of 0.2 percent from 1.38 percent to 1.33 percent.

\section{Development of Water Pollution in North Sumatera Province}

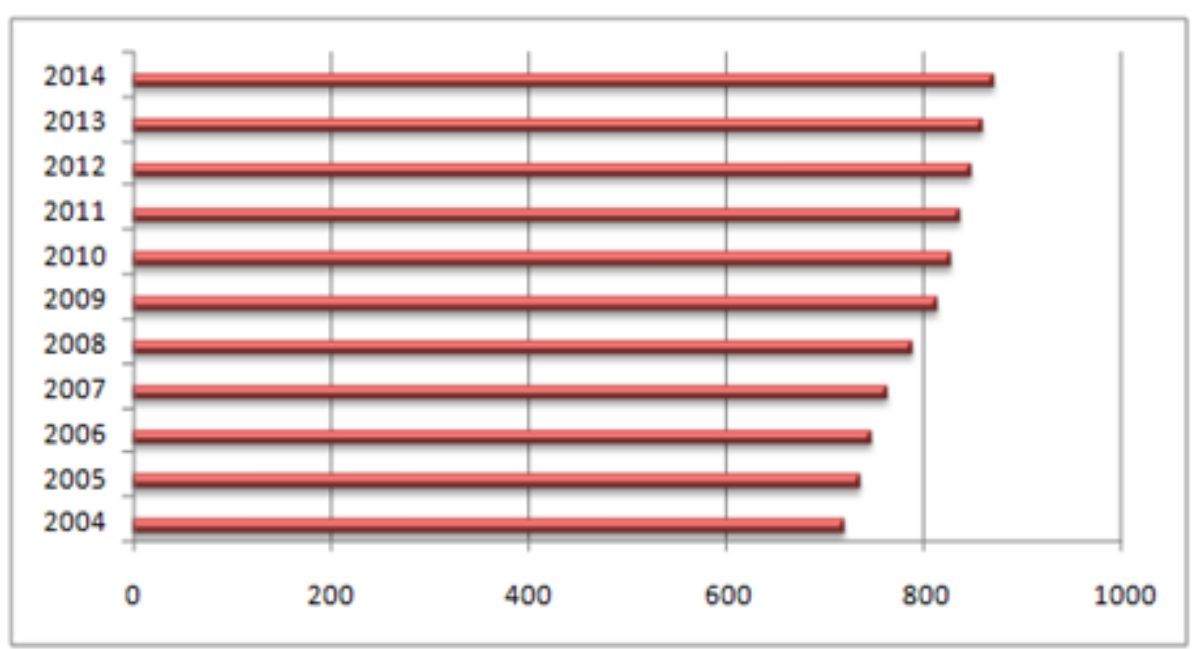

Figure 4: Water Pollution in North Sumatera Province period 2004-2014

Based on the Figure above, it is known that water pollution increased every year; it is the negative externalities impact of community activities that become worse over time. It is known that in 2004 it amounted to 721.34 tCO2eq to 871.76 tCO2eq in 2014. This means that water pollution in North Sumatera Province experienced an increase of 150.43 tCO2eq from 2004 to 2014. Furthermore, in the table above, it is known that the increase in water pollution in North Sumatera Province was the largest increase of 26CO2e in 2008 with the largest increase in CO2, 34 tCO2eq in 2007 to 789.34 tCO2eq in 2008.

\section{Development of Air Pollution in North Sumatera Province}

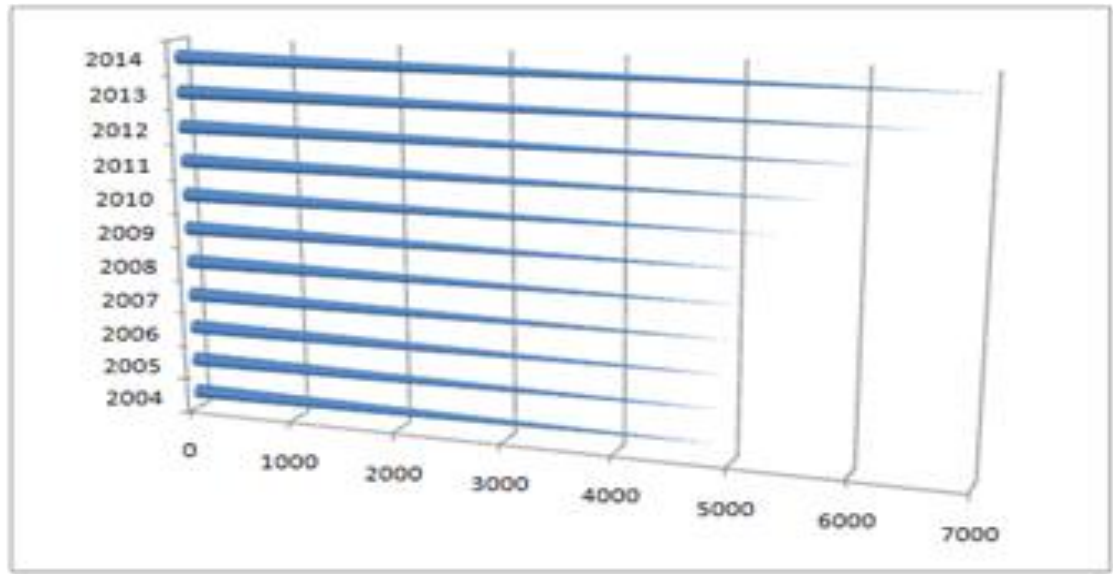

Figure 5: Air Pollution Transportation in North Sumatera Province Period 2004-2014 
Based on the figure, it is known that every year air pollution increased, it is the impact of negative externalities from community activities that the longer the air pollution is getting worse. It is known that in 2004 it amounted to 4,889.4 tCO2eq to 6,997.6 tCO2eq in 2014. This means that air pollution in North Sumatera province experienced an increase of 2,108.2 tCO2eq from 2004 to 2014. Furthermore, in the table above, it is known that the increase in air pollution in North Sumatera Province was the highest increase in CO2 in 2013 to 6,997.6 tCO2eq in 2014.

\section{Development of Soil Pollution in North Sumatera Province}

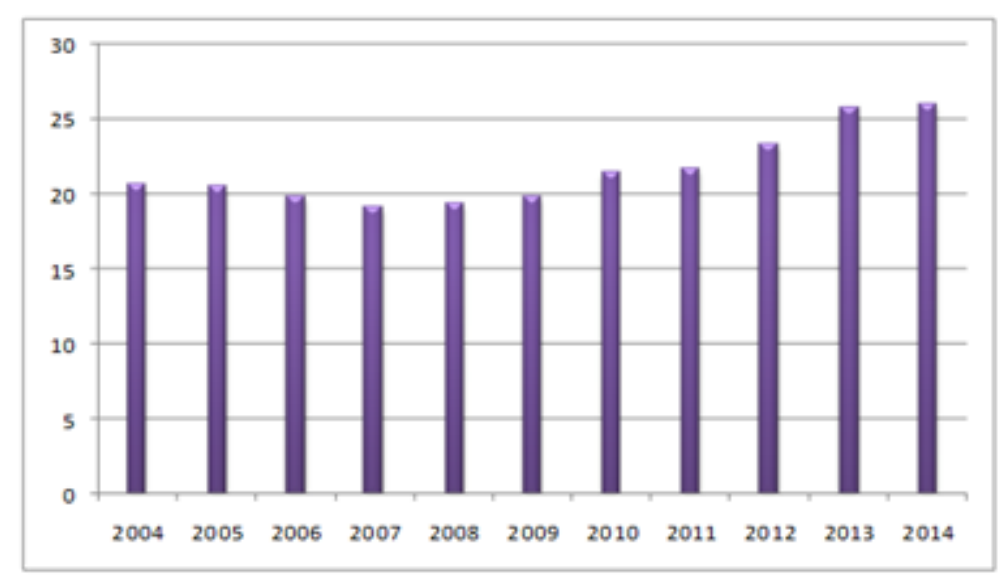

Figure 6: Soil Based Pollution of North Sumatera Province $2004-2014$

Based on the table above, it is known that soil pollution tends to increase every year. This is the impact of negative externalities from the economic activities of the community which are increasingly resulting in worsening soil pollution. It is known that in 2004 it was 20.7 percent to 26 percent in 2014. This means that land pollutants in the province of North Sumatera in 2014 experienced an increase of 5.3 per year in 2004. Furthermore, in the table above, it is known that the increase in land pollution in North Sumatera Province occurred in 2013 with an increase of 2.5 percent from 23.3 percent in 2012 to 25.3 percent in 2012, 8 percent in 2013.

\section{Discussion on the Estimation Results of the Environmental Quality in North Sumatera Province}

\section{Discussion of Assumptions}

The discussion of the assumption test in this research discusses the normality test. Testing of the normality test obtained the results of the Prob value. Jacque Berra (JB)> 0.05 means that $\mathrm{Ho}$ is rejected, meaning that there is no deviation from the normality assumption or disturbance / residuals that are normally distributed in that variable. Based on this test, the normality test results obtained in this study are as follows:

Table 3: Normality Test

\begin{tabular}{|l|l|l|l|l|l|}
\hline & \multicolumn{1}{|c|}{ KLH } & \multicolumn{1}{c|}{ PDRB } & \multicolumn{1}{c|}{ PA } & \multicolumn{1}{c|}{ PT } & \multicolumn{1}{c|}{ PU } \\
\hline Mean & 1.572727 & 271.3370 & 801661.1 & 21.60909 & 5488.318 \\
\hline Median & 1.600000 & 236.3530 & 813576.0 & 20.70000 & 5078.400 \\
\hline Maximum & 1.900000 & 523.7710 & 871765.0 & 26.00000 & 6997.600 \\
\hline
\end{tabular}




\begin{tabular}{|l|l|l|l|l|l|}
\hline Minimum & 1.270000 & 118.1000 & 721342.0 & 19.20000 & 4889.400 \\
\hline Std. Dev. & 0.227864 & 133.1093 & 52952.94 & 2.429179 & 736.4561 \\
\hline Skewness & -0.053219 & 0.726673 & -0.206544 & 0.910054 & 1.011729 \\
\hline Kurtosis & 1.667891 & 2.365054 & 1.596433 & 2.430873 & 2.593333 \\
\hline & & & & & \\
\hline Jarque-Bera & 0.818511 & 1.152879 & 0.981127 & 1.666821 & 1.952392 \\
\hline Probability & $\mathbf{0 . 6 6 4 1 4 4}$ & $\mathbf{0 . 5 6 1 8 9 5}$ & $\mathbf{0 . 6 1 2 2 8 1}$ & $\mathbf{0 . 4 3 4 5 6 5}$ & $\mathbf{0 . 3 7 6 7 4 1}$ \\
\hline & & & & & \\
\hline Sum & 17.30000 & 2984.707 & 8818272. & 237.7000 & 60371.50 \\
\hline Sum Sq. Dev. & 0.519218 & 177180.8 & $2.80 \mathrm{E}+10$ & 59.00909 & 5423675. \\
\hline & & & & & \\
\hline Observations & 11 & 11 & 11 & 11 & 11 \\
\hline
\end{tabular}

Based on the above table we know the value of Prob. JB all variables $>0.05$, so it can be concluded that there was no violation of the normality test in all variables in this study.

\section{Correlation Analysis}

Based on the results of the calculation of the correlation test of environmental quality with the independent variables of economic growth, water pollution, and soil pollution have a positive correlation. The summary of the results of the calculation of the correlation test for this research model is as follows:

Table 4: Correlation Results between Environmental Quality (KLH) and PDRB, Water Pollution (PRA), Soil Pollution (PRU), and Soil Pollution (PRT)

\begin{tabular}{|c|c|c|c|c|c|c|}
\hline \multicolumn{7}{|c|}{ Correlations } \\
\hline & & $\mathrm{KLH}$ & PDRB & $\mathrm{PA}$ & PU & $\mathrm{PT}$ \\
\hline \multirow{3}{*}{ KLH } & Pearson Correlation & 1 & $-.945^{\circ}$ & $-.969^{-}$ & $-.903^{-1}$ & $-.803^{-}$ \\
\hline & Sig. (2-tailed) & & .000 & .000 & .000 & .003 \\
\hline & $\mathrm{N}$ & 11 & 11 & 11 & 11 & 11 \\
\hline \multirow{3}{*}{ PDRB } & Pearson Correlation & $-.945^{\circ}$ & 1 & $.929^{\circ}$ & $.977^{\circ}$ & $.919^{*}$ \\
\hline & Sig. (2-tailed) & .000 & & .000 & .000 & .000 \\
\hline & $\mathrm{N}$ & 11 & 11 & 11 & 11 & 11 \\
\hline \multirow{3}{*}{$\mathrm{PA}$} & Pearson Correlation & $-.969^{-}$ & $.929^{\circ}$ & 1 & $.855^{\circ}$ & $.759^{*}$ \\
\hline & Sig. (2-tailed) & .000 & .000 & & .001 & .007 \\
\hline & $\mathrm{N}$ & 11 & 11 & 11 & 11 & 11 \\
\hline \multirow{3}{*}{ PU } & Pearson Correlation & $-.903^{-}$ & $.977^{\circ}$ & $.855^{\circ}$ & 1 & $.961^{*}$ \\
\hline & Sig. (2-tailed) & .000 & .000 & .001 & & .000 \\
\hline & $\mathrm{N}$ & 11 & 11 & 11 & 11 & 11 \\
\hline \multirow{3}{*}{ PT } & Pearson Correlation & $-.803^{*}$ & $.919^{*}$ & $.759^{\circ}$ & $.961^{*}$ & 1 \\
\hline & Sig. (2-tailed) & .003 & .000 & .007 & .000 & \\
\hline & $\mathrm{N}$ & 11 & 11 & 11 & 11 & 11 \\
\hline
\end{tabular}

**. Correlation is significant at the 0.01 level (2-tailed).

Source: Data processed with SPSS 20.

Based on the table above, it is known that the correlation value is as follows:

1. The relationship between economic growth (GRDP) and environmental quality $(\mathrm{KLH})$ is known as correlation coefficient is 0.945 . This means that the relationship between environmental quality and economic growth is very strong. 
Hence the prob value. $0.00<0.05$, which explains that there is a negative and significant relationship between economic growth and environmental quality in North Sumatera Province.

2. The relationship between water pollution (PRA) and environmental quality (KLH) is known that the correlation coefficient is 0.969 . This means that the close relationship between environmental quality and water pollution is very strong. Hence the Prob value. $0.00<0.05$, explaining that there is a negative and significant relationship between water pollution and environmental quality in North Sumatera Province.

3. The relationship between soil pollution (PRU) and environmental quality (KLH) have a correlation coefficient of 0.903 . This means that the relationship between environmental quality and soil pollution is very strong. Hence the Prob value. $0.00<0.05$, explaining that there is a negative and significant relationship between soil pollution and environmental quality in North Sumatera Province.

4. The relationship between soil pollution (PRT) and environmental quality (KLH) is known that the correlation coefficient is 0.803 . This means that the close relationship between environmental quality and soil pollution is strong. Hence the prob value. $0.00<0.05$, explaining that there is a negative and significant relationship between soil pollution and environmental quality in North Sumatera Province.

\section{Determinant Coefficient / Model Fit $\left(\mathbf{R}^{2}\right)$}

\begin{tabular}{|c|c|c|c|c|}
\hline \multicolumn{5}{|c|}{ Model Summary } \\
\hline Model & $\mathrm{R}$ & R Square & $\begin{array}{l}\text { Adjusted R } \\
\text { Square }\end{array}$ & $\begin{array}{c}\text { Std. Error of the } \\
\text { Estimate }\end{array}$ \\
\hline 1 & $.984^{\mathrm{a}}$ & .968 & .947 & .05227 \\
\hline
\end{tabular}

Based on the table above, it is known that the $R^{2}$ squared value is 0.968 . This shows that the variables of GRDP, water pollution, air pollution and land pollution are able to explain the environmental quality model in North Sumatera Province by 96.8 percent. And the remaining 3.2 percent is influenced by other variables not examined in this study.

\section{Discussion of Research Variables}

\section{Variable GRDP with Environmental Quality in North Sumatera Province}

The relationship between economic growth (GRDP) and a decrease in environmental quality $(\mathrm{KLH})$ is known to have a correlation coefficient of 0.945 . This means that the relationship between environmental quality and economic growth is very strong. Hence the prob value. $0.00<0.05$, which explains that there is a negative and significant relationship between economic growth and environmental quality in North Sumatera Province. 
This is a theory of (Fauzi, 2004). Economic growth and economic development based on natural resources that do not pay attention to environmental sustainability ultimately have a negative impact on the environment itself.

Lee, Chung, and Koo (2005) Conventional economics tends to study economic systems without paying attention to environmental factors and their sustainability, and the spurs trade-off between economic growth and environmental quality.

Pezzey (1992) describes the relationship between the economy and the environment in more detail which is called "economic and environmental stock and flows - a general model." The dependence of production on the environment is called environmental productivity, that is, the impact of economic growth on the level of production is negative. So that if the environmental quality deteriorates, it means low production.

(Grafton, et al., 2004) stated that economic activity can also produce diverse impacts or reduce the usability of others. The state of a process that can cause benefits or losses to others is called an externality.

(Howe, 1976) Considering the value of environmental damage is not taken into account by economic actors in carrying out their activities, this kind of condition will result in continuous environmental damage.

In previous research by Najmulmunir (2001), entitled "The Impact of Economic Development Policy on Regional Development and Environmental Quality, An Integrated Input Output Approach (Case of Lampung Province)". The purpose of his research is to analyze the impact of economic development policies on regional development and environmental quality. The results obtained are that the benefits of resources are concentrated in areas where the resources are located but the added value is enjoyed by other regions. The economic development of Lampung Province shows a gap. The production system creates negative externalities. Many factors affect the decline in the quality of the environment in society, one of which is the increase in economic growth which is proxies by the value of GRDP. This of course can be understood as the greater the value of GRDP, the more economic activities or activities in the community. The development of economic activities in this society will undoubtedly have a negative externality impact on the surrounding environment. Therefore, the results of this study indicate that the greater the GRDP, the lower the quality of life in North Sumatera Province.

\section{Variable of Water Pollution with Environmental Quality in North Sumatera Province}

The relationship between water pollution (PRA) and a decrease in environmental quality $(\mathrm{KLH})$ is known to have a correlation coefficient of 0.969 . This means that the close relationship between environmental quality and water pollution is very strong. Hence the prob value. $0.00<0.05$, explaining that there is a negative and significant relationship between water pollution and environmental quality in North Sumatera Province

A research conducted by Santoso (2005) stated that air pollution is the biggest contributor to the reduction of the quality of the living environment. 
According to Thomas (2000), one way to identify pollutants as air pollutants that cause environmental damage is to distinguish the pollutants from. There are 2 sources of pollutants that cause environmental degradation, known as: 1 . Natural pollutants that arise from non-artificial processes in nature, such as gases released by animals and particles from volcanic eruptions. 2. Anthropogenic pollutants, pollutants originating from the impact of human activities and include all residues associated with consumption and production

The previous relevant study by Kahuthu (2006), he conducted a study to analyze the relationship between economic growth and environmental degradation in 84 countries from 1960 to 2000. Environmental indicators used were CO2 and forest cover. Using panel data analysis with the Fixed Effect Model (FEM). The results of this study prove that there is a significant relationship between $\mathrm{CO} 2$ emissions and a reduction in environmental quality.

Amiri and Mehrara (2011) conducted a study on the relationship between pollution, energy and economic growth in India, China and Brazil in the 1960-2006 periods. This study applies a non-linear model, namely the Panel Smooth Transition Regression (PSTR) model and took into account the endogeneity bias. The results of this study indicate that energy consumption is increasingly leading to environmental damage.

Ming-Feng; and Shaw (2002), "Economic Growth and The Environmental Kuznets Curve in Taiwan: A Simultaneity Model Analysis". The variables used in this study were per capita income, air pollution levels ( $\mathrm{CO}$ and $\mathrm{NO}^{2)}$. The purpose of this study was to test the EKC hypothesis with a simultaneous model, named the reciprocal relationship between air pollution and a decrease in the quality of the environment. The results obtained in this study are the proven EKC hypothesis for the cases of $\mathrm{CO} 2$ and $\mathrm{NO}^{2}$.

One of the factors affecting the decline in the quality of the environment in society is an increase in air pollution. More and more community activities and community activities will certainly result in pollution. The more motorized vehicles, both 2,4 wheels and trucks, as well as the increasing number of industrial activities, causes more air pollution which can reduce the quality of the environment in North Sumatera Province. Therefore, the results of this study indicate that the greater the air pollution, there is a tendency to further reduce the quality of the environment in North Sumatera Province.

\section{Variable of Soil Pollution with Environmental Quality in North Sumatera Province}

The relationship between soil pollution (PRT) and a decrease in environmental quality $(\mathrm{KLH})$ is known to have a correlation coefficient of 0.803 . This means that the close relationship between environmental quality and soil pollution is strong. Hence the prob value. $0.00<0.05$, explaining that there is a negative and significant relationship between soil pollution and environmental quality in North Sumatera Province.

This is a theory (Ministry of Forestry, 2000). Critical land is the main indicator of soil degradation that can occur inside and outside forest, and reaching up hectares in size. In practice, the designation of critical land refers to the definition of critical land which 
is defined as land that has experienced damage, resulting in loss or reduction of land use up to tolerance limits.

In previous studies conducted by Grepperud (1997), "Poverty, Land Degradation and Climatic Uncertainty". In his research, he aims to study farmers operating in a risky environment at a minimum subsistence level. The results obtained from his research indicate that subsistence farmers' efforts to cover their budget deficit tend to deplete land fertility compared to non-subsistence farmers.

Holden, et. Al (2005), "Policy Analysis for Sustainable Land Management and food Security in Ethiopia". The variables used in this study were policy choices (fertilizer credit \& off-farm employment), land productivity, income, and poverty. The aim of the study was to assess the potential impact of policy options (fertilizer credit, off-farm employment) on soil management, productivity, food security and poverty. The results obtained in his research are that the two policies are proven to have an impact on increasing land productivity and income, thereby encouraging soil conservation.

Gupito and Kodoatiel (2013) conducted a study entitled "The Relationship of PDRB Per Capita from Industry, Transportation, Agriculture and Forestry Sectors to Environmental Quality Measured from COx Emissions in Central Java". The panel data analysis method in this thesis uses the Multiple Linear Regression model with the OLS method. The analysis used is the analysis of the econometric and statistical model estimation along with the economic analysis according to panel data regression. From the statistical results it can be seen that, there are several independent variables in this study that have no significant effect on the variables associated with $\mathrm{CO}_{2}$ emissions, including GRDP of the agricultural and industrial sectors, while the significant ( $5 \%$ significance) is the PRDB of the forestry and transportation sectors. .

One of the factors affecting the decline in the quality of the environment in society is the increase in soil pollutants as a result of community activities. Soil contamination often occurs as a result of the penetration of hazardous pesticides and insecticides which can reduce soil quality, thus making the soil contaminated and unfit for use.

\section{CONCLUSIONS AND RECOMMENDATIONS}

\section{Conclusion}

1. The results of the correlation coefficient analysis in this study explained that GRDP, water pollution, and air pollution have a negative and very strong relation, while oil pollution has a negative and has a strong affair with the quality of the environment in North Sumatera Province.

2. The result of this study indicates that, water pollution has the highest relationship with the quality of the environment in North Sumatera Province.

3. The variables of GRDP, water pollution, air pollution and soil pollution are able to explain the environmental quality model in Sumatera Province.

4. In the development of economic growth, it is required to concern to limitation of environmental damage, according to the theory of the limit of environmental damage between $30 \%$ and $70 \%$. 
5. The results showed that the level of environmental damage beyond the limits of environmental damage, it is necessary to pay attention to and reduce the level of environmental damage by applying sustainable economic concepts and green economic concepts.

\section{Suggestion}

1. From the results of the estimate, it shows that the variable of water pollution has the greatest impact on the quality of the environment in North Sumatera Province. This should be the concern of both Government and the private sector. Together to continue to improve the quality of life through green economic growth that needs social accountable, economic and environmental aspects.

2. The aspiration of this research that the major role of the authorities as regulator will be more enhanced in overseeing and making policies that support the creation of quality economic growth while maintaining its limitations with more stringent sectors that have a negative impact on the environment.

3. Local governments and the central government should optimize the polluter pay principle through the application of retribution and / or tax in accordance of Law Number 23 of 1997 articles 34 and 35 concerning the Principles of Environmental Management as have been reaffirmed in the field of income protection and environmental management in the field of income and environmental management,

4. The Data and the research regarding the environment are less interest among researchers and students, for the limitation of practical data research, the institutions engaged in the data sector are advised to dig more data and research related to the environmental study. Highly advised and request to continue this research for other researchers to do more research related to the environment and the economy.

\section{REFERENCES}

Adimihardja, Kusnaka\&Hikmat, Harry, (2003) Participatory Research Appraisal: Pengabdian dan Pemberdayaan Masyarakat. PenerbitHumaniora Bandung.

Albers, Henry, (1969). Principles of Management, A Modern Approach, Wiley International: New York.

Andreoni, James \& Levinson, Arik (2004). The simple analytics of the environmental KuznetCurve," Journal of Public Economics.

Arsyad, Lincoln, (1992). MemahamiMasalahKemiskinan di Indonesia: SuatuPengantar, JEBI No. 1 Tahun VII FakultasEkonomi UGM: Yogyakarta.

Arep, Ishak dan Tanjung, Hendri., (2003). ManajemenMotivasi. Penerbit PT Grasindo Jakarta.

Ashari. (2003). Tinjauan tentang alih fungsi lahan sawah ke non sawah dan dampaknya di Pulau Jawa. Forum Penelitian Agro Ekonomi, 21(2), 83-98. 
Barbier, E. B. (1989) . Cash Crops, Food Crops, and Sustainability: The case of Indonesia. WorldDevelopment, 17(6), 879-895.

Barbier, E. B. (1995). The Economics of soil rosion: Theory, methodology, and examples. Paper basedon a presentation to the Fifth Biannual Workshop on Economy and Environment in Southeast Asia. Singapore.

Cannon, J. (1999). Participatory economic valuation of natural resources in the Togean Islands.

Chambers, Robert, (1983). Rural Development, Putting the Last First, Longman: London.

Chandra, Eka, dkk., (2003). Membangun Forum Warga: ImplementasiPartisipasi dan Penguatan Masyarakat Sipil. PenerbitAkatiga Bandung.

Christina, dkk (2001) Jaman Daulat Rakyat: dariOtonomi Daerah keDemokrasi. PenerbitLaperaPustaka Utama Yogyakarta.

Cooke, Bill \& Uma Kothari (2001) Partisipation: The New Tyranny? Penerbit Zed Books London

Denison, E.F. (1979). Accounting for Slower Economic

Growth: The United States in the1970s, Washington, D.C.: The Brookings Institution.

Djajadinigrat, 2001 Untuk Generasi Masa Depan: "Pemikiran, Tantangan dan Permasalah Lingkungan", ITB.

Djojohadikusumo, Sumitro, Indonesia Dalam Perkembangan Dunia : Kinidan Masa Datang, Jakarta : LP3ES, Cet. Kelima, 1981

Effendi, Sofyan, dkk, (1993). Membangun Martabat Manusia, Perananllmu-ilmu Sosialdalam Pembangunan. Penerbit Gajah Mada University Press kerjsamadengan HIPIIS Cab. Yogyakarta.

Elang Lilik, 2003 Kumpulan Makalah Perubahan Lingkungan Global dan kerjasama Internasional, IPB

Emil Salim (dalamBrata, ed., 1992 : 3-4), pembangunanberkelanjutan (sustainable development)

Esmara, Hendra, (1986). Perencanaan dan Pembangunan di Indonesia, Gramedia: Jakarta.

Evers, Dieter \& Hans, (1988). Teori Masyarakat: Proses PeradabandalamSistem Dunia Modern. Penerbit Yayasan Obor Indonesia. Jakarta.

Fauzi.A. 2004, Ekonomi Sumber Daya Alam dan Lingkungan, Teori dan Aplikasi, Gramedia Pustaka Utama, Jakarta

Fauzi, (2010) Our Common Future and Environment, Permanetal

Grossman, G.M. dan A.B. Krueger, (1994). Economic Growth and The Environment, NationalBureu of Economic Research. 
Grafton, R.Q., Adamowicz, W., Dupont, D., Nelson, H., Hill, R.J., and Renzetti, S. (2004). TheEconomics of the Environment and Natural Resources. Carlton: Blackwell.

Haris, (2000), Konsep Pembangunan Ekonomi yang Berkelanjutan,Tiga Aspek Pemahaman Ekonomi berkelanjutan.

Hasmanto, (2001), Indikator Pencemaran Air. Tiga Aspek Pemahaman Pencemaran Air

Heal,G. 1998 Valuing the Future : Economic Theory and Sustainability. Columbia University Press. New York.

Hutabarat, Lamhot, (2010). Pengaruh PDRB Sektor Industri Terhadap Kualitas Lingkungan Ditinjau Dari Emisi Sulfur dan CO2 di Lima Negara Anggota Asean Periode 1980-2000. Skripsi Fakultas Ekonomi Universitas Diponegoro.

Idris, (2003). Penerapan Konsep Sustainable Development Sebagai Langkah Strategis Untuk Mempersiapkan Masa Depan Bangsa, Artikel Jurnal

Lee, Chung, dan Koo (2005), Traditional economic theory posits a trade-off between economic and environmental quality. Artikel Jurnal

Leontief, W. (1970). Environmental Trepercussions and the Economic Structure: An Input- Output Approach, The Review of Economics and Statistics, 52 (3 1970).

Kartasasmita, Ginandjar, Pembangunan Untuk Rakyat : MemadukanPertumbuhan dan Pemerataan, Jakarta : CIDES, 1996., Administrasi Pembangunan, Jakarta : LP3ES, 1997.

Mason, Robin \& Swanson, Timothy, (2002). "The Cost of uncoordinated regulation," European Economic Review.

Monke, E. A., and Pearson, S. R. (1989). The Policy Analysis Matrix for Agricultural Development. Ithaca: Cornell Univ. Press.

Mourato, S., Ozdemiroglu, E., and Foster, V. (2000). Evaluating health and environmental impacts of pesticide use: Implications for the design of ecolabels and pesticide taxes. EnvironmentalScience and.Technology, 34(8), $1456-1461$

Munasinghe, M. and Cruz W, (1995). Economy Wide Policies and the Environment: Lesson from Experience, World Bank Environment Paper No. 10.

Muller-Furstenberger, G, Wagner M., Muller Benito, (2004). Exploring the Carbon Kuznets Hypothesis, Oxford Institute for Energy Studies. ECONOMAC Volume II No. 2 FEUNP Padang.

Rachbini, Didik J., Teori Tentang Birokrasi dan Peranan Negara DalamSistem Ekonomi, Diktat Kuliah "Ekonomi Politik", Jakarta : FISIPUI, 1994

Redecon,ADB, 1990 Indonesia Economic Policies For Sustainable Development, ADB Publication.

Rozan, A. (2004). Benefit transfer: A comparison of WTP for air quality between France and Germany. Environmental and Resource Economics, 29, 295-306.

QE Journal | Vol.08 - No.01 - 33 